\title{
A Novel SNAP25-Caveolin Complex Correlates with the Onset of Persistent Synaptic Potentiation
}

\author{
Janice E. A. Braun ${ }^{1}$ and Daniel V. Madison² \\ 1Department of Physiology and Biophysics, Neuroscience Research Group, The University of Calgary, Calgary, Alberta, \\ Canada T2N 4N1, and 2Department of Molecular and Cellular Physiology, Stanford University Medical Center, Stanford, \\ California 94305-5428
}

\begin{abstract}
We have identified synaptic protein complexes in intact rat hippocampal slices using the rapid chemical cross-linking reagent paraformaldehyde. Cellular proteins were rapidly cross-linked, solubilized, separated electrophoretically by SDS-PAGE, and then identified immunologically. Multiple complexes containing syntaxin, the synaptosomal-associated protein of $25 \mathrm{kDa}$ (SNAP25), and vesicle-associated membrane protein (VAMP) were observed to coexist in a single hippocampal slice including a $100 \mathrm{kDa}$ cross-linked protein complex that exhibited the same electrophoretic migration as a member of the previously identified SDS-resistant soluble $N$-ethylmaleimide-sensitive fusion attachment protein receptor "core" of the 20 S complex. A VAMPsynaptophysin complex, reported previously in vitro, was also observed in the hippocampal slices. This study links biochemical and physiological studies involving presynaptic proteins implicated in secretion and confirms that these proteins that have been studied extensively previously in the presence of detergent do form "bona fide" cellular complexes. Importantly, we have also detected additional novel protein complexes that do not
\end{abstract}

Significant progress toward a molecular description of synaptic transmission has been made from the identification and characterization of the synaptic proteins and their interactions. Although several presynaptic protein complexes have been identified, correlating particular protein complexes with specific functions has proven to be more difficult. This is because conventional biochemical binding assays and immunoprecipitation methods rely on the formation of relatively stable, high-affinity protein-protein complexes. The use of detergent-solubilized preparations and bacterialexpressed proteins to assess these protein interactions in vitro is limited by the inability to extend such observations to physiological determinations of synaptic strength. Identification of the protein complexes implicated in synaptic transmission in intact tissue is an important step toward a molecular description of synaptic transmission.

We have examined syntaxin-, the synaptosomal-associated protein of $25 \mathrm{kDa}$ (SNAP25)-, and vesicle-associated membrane protein (VAMP)-containing complexes in intact hippocampal slices using a strategy of rapid protein cross-linking in living hippocampal

\footnotetext{
Received Dec. 23, 1999; revised May 5, 2000; accepted May 15, 2000.

This work was supported by the National Institute of Mental Health, the Silvio Conte Center for Neuroscience Research at Stanford (Grant MH48108), and the University of Calgary. We are indebted to Dr. Kristina Micheva for help with microscopy and immunostaining. We thank Dr. Steve J Smith for his kind gift of hippocampal cultures. We are grateful to Dr. Richard H. Scheller for his encouragement and helpful comments during the preparation of this manuscript and his generous gift of antibodies, especially SNAP25 and VAMP polyclonal antisera. We thank Dr. Thomas C. Sudhof for his gift of complexin antibodies. We thank Dr. Paul Kubes for his gift of human vein endothelial cells. We are indebted to Paul Pavlidis and Shu Chan-Hsu for discussion and shared results. We thank Drs. Alice Davy and Steve Robbins for their technical advice and Johanna Magga for her technical assistance.

Correspondence should be addressed to Dr. Daniel V. Madison at the above address.E-mail madison@leland.stanford.edu.

Copyright (C) 2000 Society for Neuroscience $0270-6474 / 00 / 205997-10 \$ 15.00 / 0$
}

correspond to complexes identified previously in vitro. After the induction of persistent synaptic potentiation, an abundant 40 kDa SNAP25-caveolin1 complex was observed. The SNAP25caveolin1 complex was not abundant in control slices and, therefore, represents the first demonstration of a reorganization of protein complexes in intact hippocampal slices during the induction of synaptic potentiation. The interaction between caveolin1 and SNAP25 was confirmed biochemically by demonstration of the association of caveolin with recombinant-immobilized SNAP25 and by the coimmunoprecipitation of SNAP25 using caveolin-specific antisera. Caveolin1, like SNAP25, was observed to be abundant in isolated hippocampal nerve terminals (synaptosomes). Immunofluorescent studies demonstrated that both SNAP25 and caveolin1 are present in neurons and colocalize in axonal varicosities. These results suggest that a shortlasting SNAP25-caveolin interaction may be involved in the early phase of synaptic potentiation.

Key words: synaptic protein; caveolin; SNAP25; hippocampus; synaptic potentiation; paraformaldehyde slices before detergent solubilization. These complexes were studied in the presence and absence of Schaffer collateral stimulation in area CA1 of the hippocampal slice. Neurotransmission is known to be modulated by activity, and such modulation is a common feature of synaptic plasticity that is thought to contribute to memory formation. Because temporary or long-term changes in these protein complexes could represent a mechanism underlying synaptic plasticity, the reorganization of these complexes under conditions in which persistent synaptic potentiation was induced in hippocampal slices was examined.

\section{MATERIALS AND METHODS}

\section{Preparation of hippocampal slices}

Rat hippocampal slices were prepared by standard methods from male Sprague Dawley rats $(200-300 \mathrm{gm})$, in strict accordance with a protocol approved by the Stanford University Animal Use and Care Committee. Animals were anesthetized with inhaled halothane and then rapidly decapitated with a commercial small animal decapitator. The brain was quickly removed, and slices were prepared. For at least $1 \mathrm{hr}$ before experimentation, slices (500 $\mathrm{nm}$ thick) were stored and maintained in an interface with a moist superoxygenated atmosphere, resting on a piece of filter paper wetted with artificial CSF (ACSF; $119 \mathrm{~mm} \mathrm{NaCl}, 2.5 \mathrm{~mm} \mathrm{KCl}$, $1.3 \mathrm{mM} \mathrm{MgSO}_{4}, 2.5 \mathrm{~mm} \mathrm{CaCl}_{2}, 1 \mathrm{~mm} \mathrm{NaH}_{2} \mathrm{PO}_{4}, 26.2 \mathrm{~mm} \mathrm{NaHCO}_{3}$, and 11 $\mathrm{mm}$ glucose). From this time the hippocampal slices were managed in three different ways termed (1) "stimulated" slice, (2) "perfused" slice, and (3) "tube" slice.

Stimulated slice. A single slice was transferred to the recording chamber, where it was submerged and superfused continuously at a rate of 1-2 $\mathrm{ml} / \mathrm{min}$ with ACSF. ACSF solution was pregassed at room temperature $\left(22^{\circ} \mathrm{C}\right)$ with $95 \% \mathrm{O}_{2}$ and $5 \% \mathrm{CO}_{2}$. For extracellular field recording in area CA1, EPSPs elicited every $15 \mathrm{sec}$ were recorded with saturated $\mathrm{NaCl}$-filled glass microelectrodes. Recording electrodes were placed in the stratum radiatum. A stimulus was given at $\sim 10 \mu \mathrm{A}$ for $100 \mu \mathrm{sec}$ at $15 \mathrm{sec}$ intervals to the Schaffer collaterals in the stratum radiatum. EPSPs were filtered at $3 \mathrm{kHz}$, digitized at $10 \mathrm{kHz}$, and stored.

Perfused slice. Slices were treated the same as stimulated slices except no stimulating or recording electrodes were placed in the hippocampal slice. 
Tube slice. A single slice was transferred to a microfuge tube, where it was submerged in $1 \mathrm{ml}$ of ACSF. The ACSF was pregassed at room temperature $\left(22^{\circ} \mathrm{C}\right)$ with $95 \% \mathrm{O}_{2}$ and $5 \% \mathrm{CO}_{2}$. The $\mathrm{pH}$ of the ACSF was measured to be 7.3. The microf uge tube was tightly capped and placed on a rotating platform. Some slices remained in control ACSF, whereas others were treated with 1-10 mM 4-aminopyridine (4-AP) for $20 \mathrm{~min}$. After 20 min, the 4-AP was washed out. The $\mathrm{pH}$ of the ACSF containing $10 \mathrm{~mm}$ 4-AP was measured to be 7.5. The slices were treated with $4 \%$ paraformaldehyde for $10 \mathrm{~min}$ and solubilized. In each experiment, immunoblot analysis was performed on tube slices from a single rat.

\section{Cross-linking of intact hippocampal slices}

Hippocampal slices were perfused or incubated with $4 \%$ paraformaldehyde as indicated in the figure legends. After cross-linking, hippocampal slices were hand-homogenized $(0.25 \mathrm{ml} /$ slice $)$ in $1 \%$ Triton X-100, $10 \mathrm{~mm}$ 3 -( $N$-morpholino)propanesulfonic acid (MOPS), pH $7.0,4.5 \mathrm{mM}$ $\mathrm{Mg}\left(\mathrm{CH}_{3} \mathrm{COO}\right)_{2}, 150 \mathrm{~mm} \mathrm{KCl}, 10 \mathrm{~mm}$ glycine, and $0.5 \mathrm{~mm}$ phenylmethylsulfonyl fluoride (PMSF) and mixed end over end for $1 \mathrm{hr}$ at $4^{\circ} \mathrm{C}$. Sample buffer was added to the solubilized slice (final concentration, $1 \%$ SDS, 42 mM Tris, $\mathrm{pH}$ 6.8, 7\% glycerol, and 7\% $\beta$-mercaptoethanol). Before SDSPAGE these samples were incubated at 30,37 , or $100^{\circ} \mathrm{C}$ for $10 \mathrm{~min}$ SDS-PAGE was performed as described previously (Braun and Scheller, 1995). The following prestained molecular mass markers were run simultaneously: insulin $(4 \mathrm{kDa})$, apoprotinin $(6 \mathrm{kDa})$, lysosyme $(17 \mathrm{kDa})$, myoglobin red (22 kDa), myoglobin blue (30 kDa), ovalbumin (46 kDa), bovine serum albumin ( $74 \mathrm{kDa})$, phosphorylase $\mathrm{B}(111 \mathrm{kDa})$, and myosin heavy chain $(214 \mathrm{kDa})$ (from Bio-Rad, Hercules, CA). The sizes of severa protein complexes have been evaluated and are indicated on the left-hand side of each panel in each figure.

Paraformaldehyde-cross-linked complexes were identified in stimulated slices, perfused slices, or tube slices. No differences in syntaxin- or SNAP25-containing complexes were identified among stimulated slices, perfused slices, or tube slices (see Fig. 5; data not shown).

\section{Formation of the SDS-resistant complex}

Hippocampal slices were hand-homogenized $(0.25 \mathrm{ml} /$ slice $)$ in $1 \%$ Triton $\mathrm{X}-100,10 \mathrm{~mm}$ MOPS, pH 7.0, $4.5 \mathrm{mM} \mathrm{Mg}\left(\mathrm{CH}_{3} \mathrm{COO}\right)_{2}, 150 \mathrm{~mm} \mathrm{KCl}$, and $0.5 \mathrm{~mm}$ PMSF and mixed end over end for $1 \mathrm{hr}$ at $4^{\circ} \mathrm{C}$. Sample buffer was added to the solubilized slice (final concentration, $1 \%$ SDS, $42 \mathrm{~mm}$ Tris, $\mathrm{pH} 6.8,7 \%$ glycerol, and $7 \% \beta$-mercaptoethanol). Before SDS-PAGE these samples were incubated at either 30,37 , or $100^{\circ} \mathrm{C}$ for $10 \mathrm{~min}$.

\section{Preparation of rat hippocampal homogenate}

Rat hippocampi were hand-homogenized with a Teflon-coated homogenizer in $0.32 \mathrm{~m}$ sucrose, $10 \mathrm{~mm}$ HEPES KOH, pH 7.0, $1 \mathrm{~mm}$ EGTA, $0.1 \mathrm{~mm}$ EDTA, $0.5 \mathrm{~mm}$ PMSF, protease inhibitor cocktail (Boehringer Mannheim, Indianapolis, IN), $1 \mu \mathrm{M}$ microcystin, $1 \mu \mathrm{M}$ okadaic acid, and $1 \mathrm{~mm}$ sodium orthovanadate ( $2 \mathrm{ml}$ /hippocampus). The homogenate was centrifuged for $10 \mathrm{~min}$ at $500 \times \mathrm{g}$, and the supernatant was collected and subsequently centrifuged for $20 \mathrm{~min}$ at $20,000 \times g\left(4^{\circ} \mathrm{C}\right)$. The pellet, containing the synaptic proteins, was resuspended in $1 \%$ Triton X-100, $20 \mathrm{~mm}$ MOPS, $\mathrm{pH}$ $7.0,4.5 \mathrm{~mm} \mathrm{Mg}\left(\mathrm{CH}_{3} \mathrm{COO}\right)_{2}, 150 \mathrm{~mm} \mathrm{KCl}, 0.5 \mathrm{~mm}$ PMSF, protease inhibitor cocktail (Boehringer Mannheim), $1 \mu \mathrm{M}$ microcystin, $1 \mu \mathrm{M}$ okadaic acid, and $1 \mathrm{~mm}$ sodium orthovanadate and incubated for $30 \mathrm{~min}$ at $37^{\circ} \mathrm{C}$. After solubilization, large membrane fragments were removed by centrifugation at $1000 \times g$ for $5 \mathrm{~min}$. The resulting supernatant is a crude hippocampal homogenate that contains synaptic proteins. Protein concentrations were determined by the Bio-Rad Protein Assay using bovine serum albumin as the standard.

\section{Preparation of rat hippocampal synaptosomes}

Synaptosomes were isolated from the hippocampus by differential and discontinuous Percoll gradient centrif ugations (Nagy and Delgado-Escuta, 1984; Meffert et al., 1994). Briefly, rat hippocampi were dissected and homogenized in $0.32 \mathrm{~m}$ sucrose and $5 \mathrm{mM}$ HEPES (14 up-and-down strokes with cooling after the first 7) using a Teflon glass homogenizer. The homogenate was centrifuged for $10 \mathrm{~min}$ at $1000 \times g$ (Beckman JA-20 fixed-angle rotor), and the supernatant was collected. The supernatant was layered directly onto Percoll gradients and centrifuged for $20 \mathrm{~min}$ at $15,000 \times g$ (Beckman SW41 Ti rotor). After isolation, the synaptosomal fraction was washed, pelleted, and resuspended in ice-cold balanced salt solution (128 mM NaCl, $2.4 \mathrm{~mm} \mathrm{KCl}, 1.2 \mathrm{mM} \mathrm{MgSO}_{4}, 1.2 \mathrm{mM} \mathrm{KH}_{2} \mathrm{PO}_{4}, 10$ mM HEPES, pH 7.4, and $10 \mathrm{~mm}$ D-glucose)

\section{Preparation of fusion proteins}

Glutathione $S$-transferase fusion proteins of SNAP25 and VAMP2 were prepared as described previously (Pevsner et al., 1994). Briefly, a GST fusion protein encoding a full-length SNAP25 or the cytoplasmic portion of VAMP2 was constructed in the vector pGEX-KG (Guan and Dixon, 1991) and expressed in the AB1899 strain of Escherichia coli. After induction of expression with $100 \mu \mathrm{M}$ isopropyl- $\beta$-D-thiogalactopyranoside for $5 \mathrm{hr}$, the bacteria were suspended in PBS $(137 \mathrm{~mm} \mathrm{NaCl}, 2.7 \mathrm{mM} \mathrm{KCl}$, $10 \mathrm{~mm} \mathrm{Na} \mathrm{HPO}_{4}$, and $2 \mathrm{mM} \mathrm{KH}_{2} \mathrm{PO}_{4}$ ) supplemented with $0.05 \%$ Tween 20, 2 mM EDTA, and $0.1 \% \beta$-mercaptoethanol and lysed by two passages through a French Press (Spectronic Instruments). The fusion protein was recovered by binding of the GST domain to glutathione agarose beads (Sigma, St. Louis, MO). The fusion protein beads were washed extensively and finally resuspended in $0.5 \%$ Triton X-100, $20 \mathrm{~mm}$ MOPS, pH 7.0, 4.5 $\mathrm{mM} \mathrm{Mg}\left(\mathrm{CH}_{3} \mathrm{COO}\right)_{2}, 150 \mathrm{~mm} \mathrm{KCl}$, and $0.5 \mathrm{mM}$ PMSF.

\section{Immunoprecipitation}

Immunoprecipitation was achieved by incubating detergent-solubilized (1\% Triton X-100) hippocampal homogenate with affinity-purified anticaveolin polyclonal (Transduction Laboratories, Lexington, KY), affinitypurified anti-caveolin1 polyclonal (Santa Cruz Biotechnology, Santa Cruz, CA), rabbit nonimmune serum, or protein A/G agarose (Santa Cruz Biotechnology) for $5 \mathrm{hr}$. Samples were washed three times, resuspended in $30 \mu \mathrm{l}$ of sample buffer, separated by SDS-PAGE, transferred to nitrocellulose, and probed with antibodies. Proteins were visualized using enhanced chemiluminescence (ECL; Amersham, Arlington Heights, IL).

\section{Immunoblotting}

Proteins were transferred electrophoretically at constant voltage from polyacrylamide gels to nitrocellulose $(0.45$ or $0.2 \mu \mathrm{m})$ in $20 \mathrm{~mm}$ Tris, 150 $\mathrm{mm}$ glycine, and $12 \%$ methanol. Transferred proteins were visualized by staining with Ponceau S. Nitrocellulose membranes were blocked for nonspecific binding using 5\% milk, $0.15 \%$ Tween 20, and PBS solution (137 mM NaCl, $2.7 \mathrm{~mm} \mathrm{KCl}, 4.3 \mathrm{~mm} \mathrm{Na} 2 \mathrm{HPO}_{4}$, and $1.4 \mathrm{mM} \mathrm{KH}_{2} \mathrm{PO}_{4}, \mathrm{pH}$ 7.3) and incubated overnight with primary antibody. The membranes were washed four times in the above milk, Tween, and PBS solution and incubated for $30 \mathrm{~min}$ with goat anti-rabbit or goat anti-mouse IgG-coupled horseradish peroxidase. Antigen was detected using chemiluminescent horseradish peroxidase substrate (ECL; Amersham). Immunoreactive bands were visualized after exposure of the membranes to Amersham Hyperfilm-MP.

\section{Cell culture and immunostaining}

Primary embryonic hippocampal cultures were a kind gift from Dr. Steve J. Smith and were prepared as described previously (Banker and Goslin, 1998; Ahmari et al., 2000). Cells were fixed for $10 \mathrm{~min}$ in $100 \%$ methanol at $-20^{\circ} \mathrm{C}$, washed in PBS, and incubated for $1 \mathrm{hr}$ at room temperature or overnight at $4^{\circ} \mathrm{C}$ in PBS and $1 \%$ BSA containing either a caveolin1-specific polyclonal antibody (Santa Cruz Biotechnology), a caveolin1-specific monoclonal antibody (Transduction Laboratories), a caveolin polyclonal antibody (Transduction Laboratories), and/or a SNAP25 monoclonal (Sternberger Monoclonals). After extensive washing in PBS, cells were incubated with Cy5-conjugted affinity-pure goat anti-mouse secondary antibody (Jackson ImmunoResearch, West Grove, PA) and/or Alexa Fluor 488-conjugated goat anti-rabbit secondary antibody (Jackson ImmunoResearch) for $1 \mathrm{hr}$ followed by washing.

\section{RESULTS}

\section{SNAP25- and syntaxin-containing complexes can be identified in intact hippocampal slices before detergent solubilization}

The goal of our study was to determine the nature of SNAP25, syntaxin, and VAMP complexes that could be identified in intact tissue. To do so, field EPSPs resulting from Schaffer collateral stimulation in area CA1 of rat hippocampal slices were recorded, followed by treatment with the membrane-permeant primary amine-reactive chemical cross-linking agents DSP [dithiobis(succinimidylpropionate)] or paraformaldehyde (polymerized formaldehyde) (Fig. 1). Such treatment should capture existing protein complexes by forming covalent cross-links between neighboring proteins. As shown in Figure 1, 4\% paraformaldehyde abolishes neurotransmission almost immediately (within $30 \mathrm{sec}$ ), indicating that it quickly cross-links and disables proteins necessary for synaptic transmission. DSP (4 mM), on the other hand, only slowly and incompletely inhibits neurotransmission. Paraformaldehyde was used as the cross-linker of choice in the remaining experiments because of the speed by which it halts neurotransmission, thus making it more likely to capture physiologically relevant protein complexes. Aldehyde cross-linkers have been used extensively for imaging the interactions of synaptic vesicles at the nerve terminal (Rosahi et al., 1995; Takei et al., 1996; Fawcett et al., 1997; Betz et al., 1998; Schweizer et al., 1998).

Figure 2 demonstrates that SNAP25-containing protein complexes of 55, 60, and $100 \mathrm{kDa}$ and syntaxin-containing complexes of 60,100 , and $120 \mathrm{kDa}$ were identified when hippocampal slices were exposed to paraformaldehyde before solubilization. The protein complexes were resolved by SDS-PAGE and detected by Western blot analysis. No comparable SNAP25-containing complexes were 


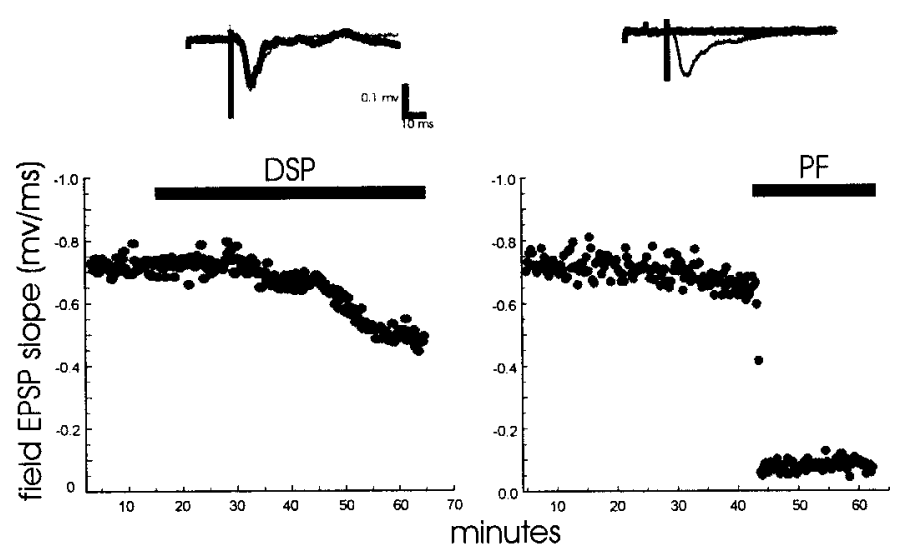

Figure 1. Field EPSP resulting from Schaffer collateral stimulation in area CA1 of a rat hippocampal slice perfused with the cross-linking agents $4 \mathrm{~mm}$ DSP or $4 \%$ paraformaldehyde $(P F)$ (stimulated slices). A stimulus was delivered every $15 \mathrm{sec}$ throughout the experiment. Left Inset, EPSPs are shown before (thin trace) or after (heavy trace) $50 \mathrm{~min}$ of $4 \mathrm{mM}$ DSP. DSP only slowly and incompletely inhibits neurotransmission. Right Inset, EPSPs are shown before (thin trace) or after (heavy trace) 11 min of 4\% PF. Paraformaldehyde abolishes neurotransmission almost immediately. These results are representative of three DSP and four PF experiments.

identified in fractions obtained from hippocampal slices that were not exposed to cross-linking agents. The cross-linked complexes were observed after exposure of the hippocampal slice to paraformaldehyde for $7 \mathrm{~min}$ and were more detectable after exposure to paraformaldehyde for 15-45 min. Syntaxin- and SNAP25containing complexes could be detected as early as 2 min after treatment with paraformaldehyde, which was the earliest time point examined (data not shown). On the basis of comigration, the 100 and $60 \mathrm{kDa}$ complexes likely contain both syntaxin and SNAP25. Syntaxin- and SNAP25-containing complexes were also identified in hippocampal slices treated with DSP for $45 \mathrm{~min}$; however, these complexes did not resolve as well as the paraformaldehyde-cross-linked complexes. Because paraformaldehyde cross-linking is rapid, it likely captures protein complexes that are short-lived equally well as more stable high-affinity proteinprotein interactions. The syntaxin- and SNAP25-containing complexes shown in Figure 2 may represent physiological complexes that are not maintained during detergent solubilization, a process that favors high- but not low-affinity protein interactions.

\section{Comparison of the cross-linked SNAP25-containing complexes and the SDS-resistant complexes}

Hayashi et al. (1994) have reported that the three synaptic proteins VAMP, syntaxin, and SNAP25 form a stable "core" $80 \mathrm{kDa}$ complex when isolated from solubilized rat brain preparations and that this complex resists dissociation by SDS in unboiled samples. Pel-

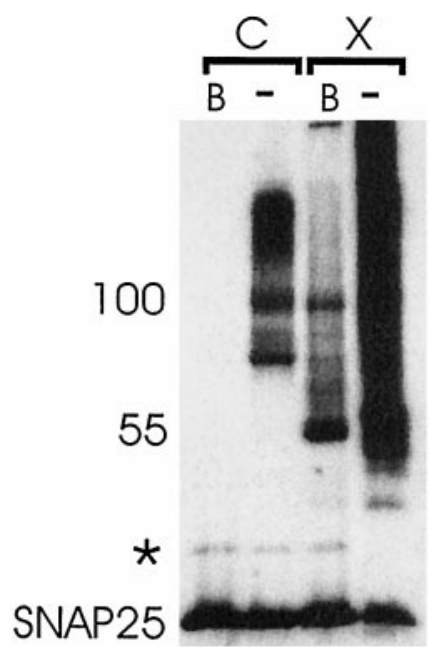

Figure 3. Western blot analysis of detergent-solubilized hippocampal slices $(C$; lanes 1,2$)$ incubated in sample buffer at $100^{\circ} \mathrm{C}(B)$ or $30^{\circ} \mathrm{C}(-)$ or cross-linked with $4 \%$ paraformaldehyde $(X$; lanes 3,4$)$ before detergent solubilization (tube slices). Forty microliters of each hippocampal homogenate were loaded on a $10 \%$ polyacrylamide gel and fractionated by PAGE. The membranes were probed with a monoclonal antibody against SNAP25 (SMI 81; Sternberger Monoclonals). The SNAP25-containing SDSresistant complexes and the cross-linked SNAP25 complexes are compared. * indicates a SNAP25-immunoreactive band that is seen in the absence as well as the presence of cross-linking agent. The results are representative of six independent experiments.

legrini et al. (1995) have reported that VAMP, syntaxin, and SNAP25 form an SDS-resistant ladder including major bands at 60 , 120 , and $160 \mathrm{kDa}$ and minor bands at 100 and $200 \mathrm{kDa}$. Figure 3 compares the electrophoretic mobility of the paraformaldehydecross-linked SNAP25-containing complexes with a SNAP25containing SDS-resistant core complex isolated from noncrosslinked hippocampal slices. After boiling in noncross-linked hippocampal slices, SNAP25 appears as a monomer (Fig. 3, lane 1). When unboiled fractions from solubilized hippocampal slices were analyzed, a ladder of immunoreactivity including monomeric SNAP25 and major bands at 80,100 , and $120 \mathrm{kDa}$ was detected (Fig. 3, lane 2). An SDS-resistant $200 \mathrm{kDa}$ SNAP25-containing complex could also be detected (data not shown). Although there are differences in the electrophoretic mobility of some members of the SDS-resistant ladder isolated from rat brain (Pellegrini et al., 1995) and rat hippocampal slices (Fig. 3, lane 2), these complexes are indistinguishable regarding their composition and disruption by boiling. The 55/60 kDa SNAP25-containing cross-linked complexes do not comigrate with an SDS-resistant complex (Fig. 3, lanes 2, 3). The comigration of the SDS-resistant and cross-linked SNAP25 complexes at $100 \mathrm{kDa}$ suggests that these complexes are

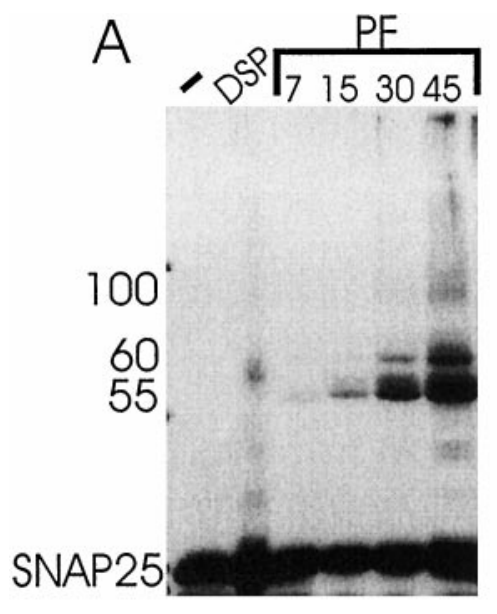

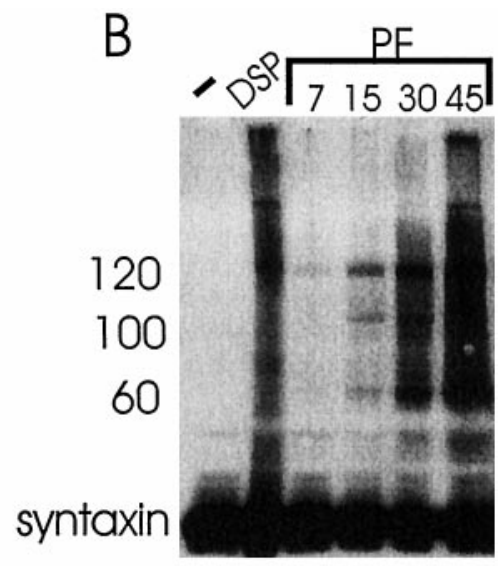

Figure 2. Western blot analysis of detergent-solubilized hippocampal slices $(-)$ and intact hippocampal slices cross-linked with $4 \mathrm{~mm}$ DSP $(D S P)$ for 45 min or $4 \%$ paraformaldehyde $(P F)$ for $7,15,30$, or 45 min before detergent solubilization (tube slices). Forty microliters of each hippocampal homogenate were loaded on a $10 \%$ polyacrylamide gel and fractionated by PAGE. Membranes were probed with anti-SNAP25 polyclonal $(A)$ or anti-syntaxin monoclonal $(B)$. Proteins were separated for different distances in $A$ and $B$ to separate the indicated complexes maximally. SNAP25- and syntaxincontaining protein complexes were identified. The molecular mass of the SNAP25- and syntaxin-containing bands were evaluated by simultaneously running molecular weight standards as described in Materials and Methods. The results are representative of four independent experiments. 


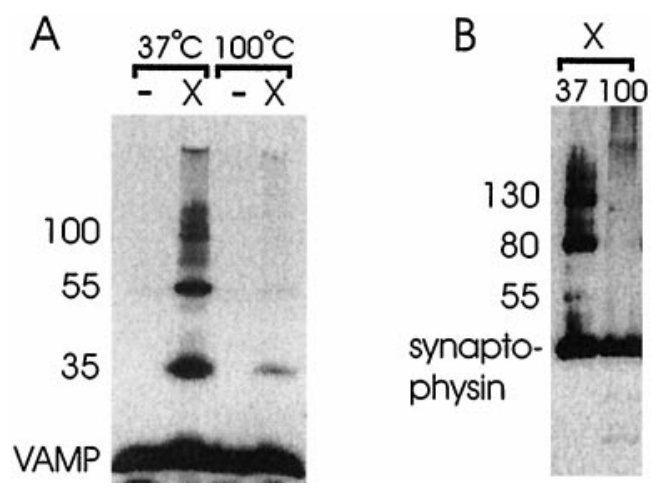

Figure 4. Western blot analysis of detergent-solubilized hippocampal slices (-) and hippocampal slices cross-linked with $4 \%$ paraformaldehyde $(X)$ before detergent solubilization (tube slices). Hippocampal slices were incubated in sample buffer at $100^{\circ} \mathrm{C}$ or $37^{\circ} \mathrm{C}$. Forty microliters of each hippocampal homogenate were loaded on a $12 \%(A)$ or $10 \%(B)$ polyacrylamide gel and fractionated by PAGE. $A$, The membranes were probed with a VAMP polyclonal antisera. $B$, The membranes were probed with a synaptophysin monoclonal antibody (Sigma). The $55 \mathrm{kDa}$ VAMPcontaining protein complex comigrates with a $55 \mathrm{kDa}$ synaptophysin protein complex. The top VAMP- and synaptophysin-containing bands represent the interface between the stacking and resolving gels. The results are representative of six independent experiments.

identical. These results suggest that the $100 \mathrm{kDa}$ band of the SDS-resistant complex exists in intact hippocampal slices before solubilization but that the other components of the SDS-resistant ladder assemble after solubilization. This $100 \mathrm{kDa}$ complex is, however, only one of several SNAP25 and syntaxin complexes identified in intact slices (Figs. 2, 3). The 55/60 kDa SNAP25containing complex is absent in solubilized (uncross-linked) hippocampus, indicating that it is disrupted by solubilization. When unboiled fractions from paraformaldehyde-cross-linked hippocampal slices were analyzed, SNAP25 was observed to assemble into large unresolved oligomeric forms (Fig. 3, lane 4). These results indicate that cross-linking SNAP25 did not preclude it from attempting to reassemble into larger oligomeric structures after solubilization. Again, the assembly of cross-linked complexes into larger oligomeric structures suggests that some of these components assemble in the presence of detergent but are not present in intact tissue.

\section{VAMP-containing complexes can be identified in intact hippocampal slices before detergent solubilization}

Although VAMP is known to be a member of the SDS-resistant core complex, some (Pellegrini et al., 1995) but not all (Hayashi et al., 1994) VAMP antibodies detect VAMP in complex. We were unable to detect VAMP in the intact SDS-resistant ladder by Western analysis (data not shown). Also VAMP-containing complexes were only poorly identified in paraformaldehyde-crosslinked hippocampal slices when samples were incubated at $100^{\circ} \mathrm{C}$ for $10 \mathrm{~min}$ (Fig. 4A). Figure $4 A$ shows that VAMP-containing protein complexes of $35,55,100$, and $120 \mathrm{kDa}$ were identified when hippocampal slices were exposed to paraformaldehyde before solubilization. Unlike syntaxin and SNAP25, VAMP-containing complexes from paraformaldehyde-cross-linked hippocampal slices were clearly detected when samples were incubated in sample buffer at $37^{\circ} \mathrm{C}$ and not $100^{\circ} \mathrm{C}$ for $10 \mathrm{~min}$. No comparable VAMPcontaining complexes were identified in fractions obtained from hippocampal slices that were not exposed to cross-linking agents. The monomer form of VAMP was also detected in fractions obtained from cross-linked hippocampal slices. The $35 \mathrm{kDa}$ VAMP-containing cross-linked complex may represent an 18-18 $\mathrm{kDa}$ VAMP dimer on the basis of its electrophoretic migration. Alternatively, it may be VAMP cross-linked to another lowmolecular mass protein of $\sim 17 \mathrm{kDa}$. The $55 \mathrm{kDa}$ VAMPcontaining band comigrates with the $55 / 60 \mathrm{kDa}$ SNAP25 crosslinked complex although the VAMP-containing complex resolves to a more discrete band. Calakos and Scheller (1994) have reported a $56 \mathrm{kDa}$ VAMP-containing complex comprised of a direct interaction of VAMP with synaptophysin. Figure $4 B$ shows that the 55 $\mathrm{kDa}$ VAMP-containing cross-linked complex comigrates with a 55 $\mathrm{kDa}$ synaptophysin-containing complex. Other synaptophysincontaining complexes were identified at 80,100,130, and $155 \mathrm{kDa}$ (Fig. $4 B$ ). These results suggest that the $55 \mathrm{kDa}$ VAMP-containing complex may be the same protein complex as that reported by Calakos and Scheller (1994).

The comigration of a VAMP-containing, a syntaxin-containing, and a SNAP25-containing complex at $100 \mathrm{kDa}$ (Figs. $2 A, B, 3$ ) suggests that a single $100 \mathrm{kDa}$ complex comprised of all three proteins exists in intact tissue. These results suggest that the 100 $\mathrm{kDa}$ complex is the physiological soluble $N$-ethylmaleimidesensitive fusion attachment protein (SNAP) receptor (SNARE) complex present in intact tissue. Of the other proteins we examined, synaptotagmin, n-sec-1, cysteine string protein, rabphillin, $N$-ethylmaleimide-sensitive fusion protein (NSF), secretory vesicle-associated protein, hepatocyte growth factor-regulated tyrosine kinase substrate 2 (HRS2), and complexin I and II did not comigrate with the $100 \mathrm{kDa}$ complex. These proteins were also absent from the other syntaxin- or SNAP25-containing complexes as examined by Western blot analysis (data not shown). Complexes containing these proteins were observed in hippocampal slices cross-linked with paraformaldehyde before solubilization; however these protein complexes were distinct from the syntaxin- and SNAP25-containing complexes on the basis of electrophoretic mobility (data not shown). In solubilized preparations, the $55 / 60 \mathrm{kDa}$ SNAP25-containing, the $60 \mathrm{kDa}$ syntaxin-containing, and the 35 and $55 \mathrm{kDa}$ VAMP-containing protein complexes identified in intact slices are absent, indicating that they are disrupted. Also, the 80 and $120 \mathrm{kDa}$ members of the SDS-resistant ladder were not present in hippocampal slices paraformaldehyde cross-linked before solubilization, indicating that these complexes assemble in the presence of detergent but do not represent physiological protein complexes. These results also indicate that syntaxin, SNAP25, and VAMP each physiologically coexist in complexes with proteins other than the members of the SNARE core complex.

\section{Schaffer collateral stimulation and synaptic protein complexes}

Figure 5 demonstrates that a stimulation protocol that involves mild stimulation at a low rate $(\sim 10 \mu \mathrm{A} ; 100 \mu \mathrm{sec}$ duration; $15 \mathrm{sec}$

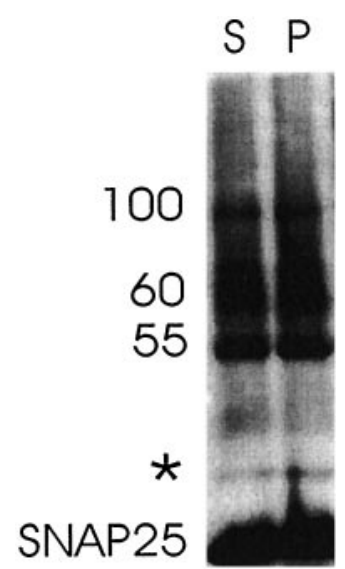

Figure 5. Western blot analysis of hippocampal slices that are either recorded every $15 \mathrm{sec}$ in area CA1 [stimulated $(S)$ slice] or not stimulated [perfused $(P)$ slice] and cross-linked with $4 \%$ paraformaldehyde before detergent solubilization. Forty microliters of each hippocampal homogenate were loaded on a $10 \%$ polyacrylamide gel and fractionated by PAGE. The membranes were probed with a monoclonal antibody against SNAP25 (SMI 81; Sternberger Monoclonals). Cross-linked SNAP25 containingcomplexes from stimulated and unstimulated slices were compared. * indicates a SNAP25-immunoreactive band that is seen in the absence as well as the presence of cross-linking agent. The results are representative of three independent experiments. 

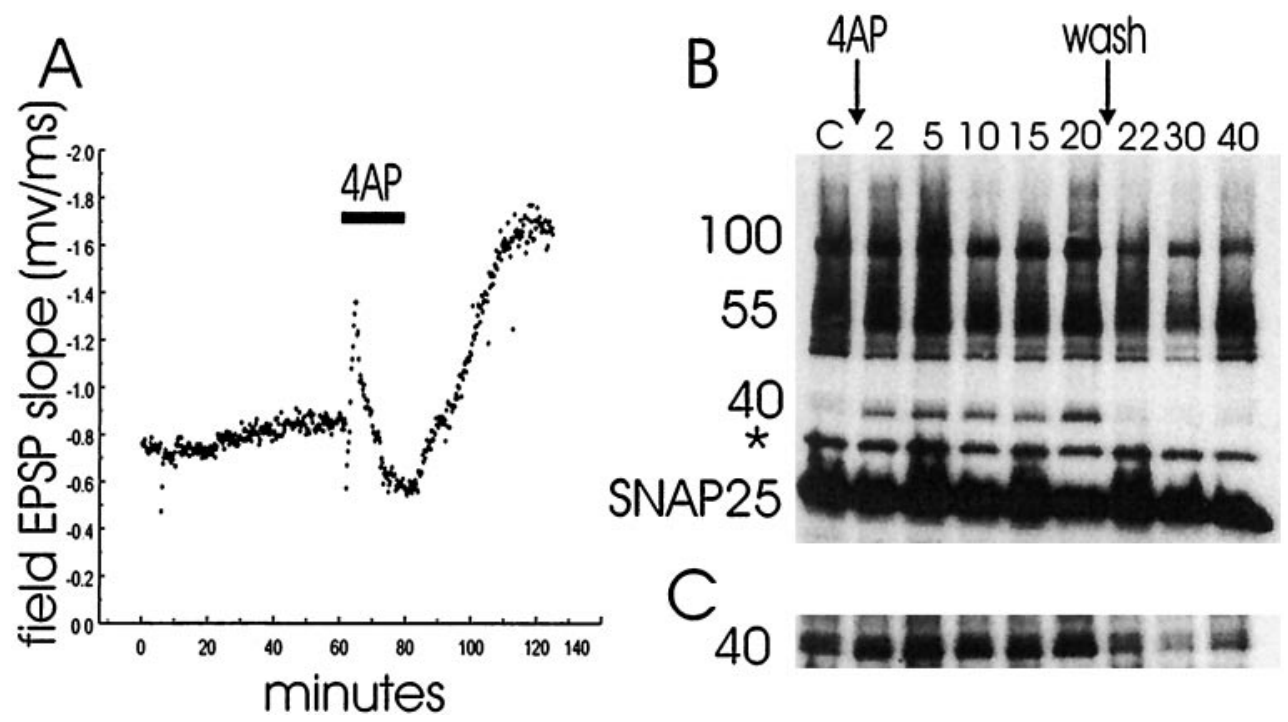

Figure 6. Time course of 4-AP induction of the $40 \mathrm{kDa}$ SNAP25-containing band. $A$, Field EPSP resulting from Schaffer collateral stimulation in area CA1 of a rat hippocampal slice treated with $10 \mathrm{~mm} 4-\mathrm{AP}$ for $20 \mathrm{~min}$ (horizontal bar labeled $4 A P$ ) followed by washout is shown. An EPSP was elicited every $15 \mathrm{sec}$ throughout the experiment. (stimulated slice) $B, C$, The lanes are as follows: lane $C$, control; lanes 2-20, 2, 5, 10, 15, 20, 22, 30, and 40 min after the hippocampal slices were treated with 4-AP (tube slices). After 20 min the 4-AP was washed out. The slices were cross-linked with 4\% paraformaldehyde for $10 \mathrm{~min}$ and solubilized. Forty microliters of each hippocampal homogenate were fractionated by SDS-PAGE and subjected to Western blot analysis. The nitrocellulose membrane was probed with anti-SNAP25 (SMI 81; Sternberger Monoclonals) and visualized by ECL. B, SNAP25-containing complexes are shown after a brief exposure to film. * indicates a SNAP25-immunoreactive band that is seen in the absence as well as the presence of cross-linking agent. $C$, The $40 \mathrm{kDa}$ SNAP25-containing complex is shown after overexposure of the film. The results are representative of five (stimulated slices) and six (tube slices) independent experiments.

intervals) does not produce detectable reorganization in SNAP25 complexes in a total hippocampal slice homogenate. This lowfrequency stimulation likely stimulates exocytosis in only a limited number of synapses even within subregions of the hippocampal slice. These results show that total hippocampal homogenates of stimulated and unstimulated slices reveal the same paraformaldehyde-cross-linked SNAP25-, syntaxin-, and VAMPcontaining complexes (Fig. 5; data not shown).

\section{A novel SNAP25-caveolin complex correlates with the onset of persistent synaptic potentiation}

The identification of specific alterations in protein complexes implicated in neurosecretion during increases or decreases in synaptic strength such as long-term potentiation (LTP) may be essential to our understanding of neurotransmission. It has been proposed, for example, that the readily releasable pool of secretory vesicles can be modified (Gillis et al., 1996). The physiological regulation of

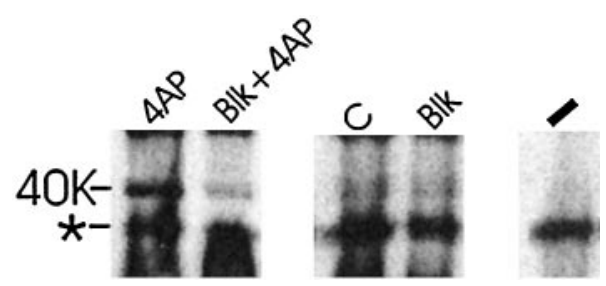

Figure 7. Western blot analysis of detergent-solubilized hippocampal slices and hippocampal slices cross-linked with $4 \%$ paraformaldehyde before detergent solubilization (tube slices). Slices were pretreated for $15 \mathrm{~min}$ in the presence or absence of the following agents: $1 \mu \mathrm{M}$ tetrodotoxin (TTX), $50 \mu \mathrm{M}$ D-2,5-aminophosphonovaleric acid (D-APV), and $100 \mu \mathrm{M}$ $\mathrm{CdCl}_{2}$. After $15 \mathrm{~min} 10 \mathrm{~mm}$ 4-AP was added to the ACSF for $20 \mathrm{~min}$ as indicated. Hippocampal slices were incubated in sample buffer at $100^{\circ} \mathrm{C}$. Forty microliters of each hippocampal homogenate were loaded on a $12 \%$ polyacrylamide gel and fractionated by PAGE. The membranes were probed with a SNAP25 monoclonal antibody (Sternberger Monoclonals). The lanes are as follows: lane $4 A P$, control ACSF and then 4-AP; lane $B L K+4 A P$, TTX, D-APV, $\mathrm{CdCl}_{2}$ and then 4-AP; lane $C$, control ACSF; lane Blk, TTX, D-APV, and $\mathrm{CdCl}_{2}$ with no subsequent addition; lane -, control ACSF not cross-linked. * indicates a SNAP25-immunoreactive band that is seen in the absence as well as the presence of cross-linking agent. The results are representative of three independent experiments. synaptic vesicle availability implies a reorganization of the series of protein complexes that underlie synaptic transmission. We have examined the paraformaldehyde-cross-linked complexes in rat hippocampal slices (Figs. 2, 4) in which a potentiation of synaptic transmission has been induced (Fig. 6) by application of the potassium channel blocker 4-AP (10 mm; $20 \mathrm{~min})$. This treatment caused a persistent potentiation of synaptic transmission as measured by an increase in the slope of field EPSPs in area CA1 (Fig. 6), in agreement with previous results (Aniksztejn and Ben-Ari, 1991). The 4-AP response was characterized by an initial enhancement followed by an inhibition in the slope of EPSPs during the application of 4-AP. After washout of 4-AP, a sustained enhancement of the slope of EPSPs was observed that lasted for at least $1 \mathrm{hr}$ (the longest time point tested) while the slice was vigorously perfused with ACSF. The high concentration of 4-AP used in these experiments was chosen because it likely induces potentiation in a larger fraction of synapses than would, for example, a tetanus stimulus. Potentiation in a large fraction of synapses is likely required for reorganization of protein complexes to be detectable in a total hippocampal slice homogenate.

An additional $40 \mathrm{kDa}$ SNAP25-containing cross-linked complex was identified in hippocampal slices treated with 4-AP (Fig. 6). This novel complex is a SNAP25-caveolin complex on the basis of immunoreactivity with anti-SNAP25 and anti-caveolin antibodies (see Fig. $8 A$ ). Figure $6 B$ demonstrates that the SNAP25-containing protein complex of $40 \mathrm{kDa}$ was clearly detected in hippocampal slices during 4-AP treatment but was not observed in hippocampal slices after the washout of 4-AP or in control hippocampal slices (not treated with 4-AP). The $40 \mathrm{kDa}$ complex was detected as early as 2 min (the earliest time point tested) after exposure to 4-AP and was present throughout the duration of the 4-AP treatment. The complex was detected at concentrations as low as $1 \mathrm{~mm}$ 4-AP (data not shown). The absence of the $40 \mathrm{kDa}$ complex could be detected as early as 2 min after 4-AP washout (the earliest time point tested). Although the 4-AP response was characterized by an initial enhancement followed by an inhibition in the slope of EPSPs, the $40 \mathrm{kDa}$ band was present throughout the entire enhancement/ inhibition phase of the 4-AP treatment. The other SNAP25containing complexes $(55 / 60$ and $100 \mathrm{kDa})$ were not observed to 

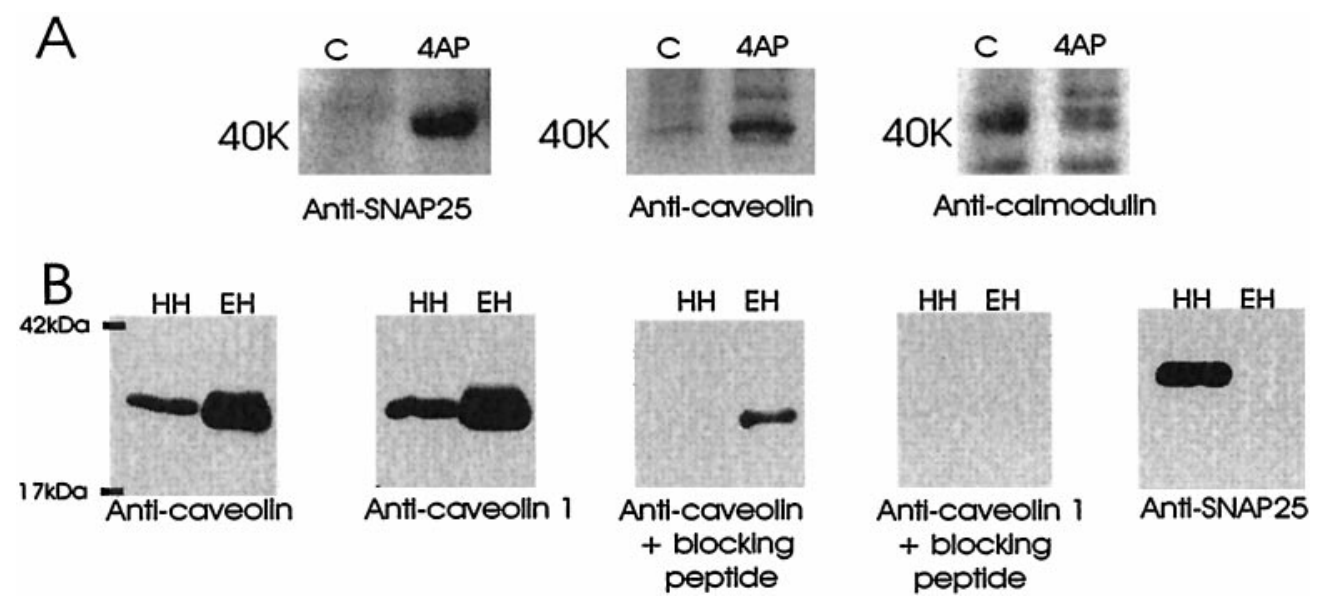

Figure 8. A, 4-AP induction of a $40 \mathrm{kDa}$ caveolin-containing band. Western blot analysis of control $(C)$ and 4-AP-treated (4AP) rat hippocampal slices (tube slices) is shown. The slices were treated with $10 \mathrm{~mm} \mathrm{4-AP} \mathrm{for} 20 \mathrm{~min}$ and then cross-linked for 10 min and solubilized. Forty microliters of each hippocampal homogenate were fractionated by SDS-PAGE and subjected to Western blot analysis. The nitrocellulose membrane was probed with the following (left to right): panel 1, anti-SNAP25 monoclonal (Sternberger Monoclonals); panel 2, anti-caveolin polyclonal (Transduction Laboratories); and panel 3, anti-calmodulin monoclonal (Upstate Biotechnology, Lake Placid, NY). The panels represent separate Western blots of the same homogenates. The $40 \mathrm{kDa}$ immunoreactive band is indicated. $B$, Immunoblot analysis of rat hippocampal homogenate $(H H ; 45 \mu \mathrm{g})$ and human vein endothelial cell homogenate $(E H ; 1 \mu \mathrm{g})$ demonstrating the specificity of the caveolin and SNAP25 antibodies. The panels represent separate Western blots of the same homogenates. The nitrocellulose membrane was probed as indicated (left to right) with the following: panel 1, anti-caveolin polyclonal (Transduction Laboratories); panel 2, anti-caveolin1 polyclonal (Santa Cruz Biotechnology); panel 3, anti-caveolin polyclonal (Transduction Laboratories) preincubated with a peptide corresponding to the $\mathrm{N}$ terminal of caveolin1 (Santa Cruz Biotechnology); panel 4, anti-caveolin1 polyclonal (Santa Cruz Biotechnology) preincubated with a peptide corresponding to the $\mathrm{N}$ terminal of caveolin1 (Santa Cruz Biotechnology); and panel 5, anti-SNAP25 monoclonal (Sternberger Monoclonals). These results are representative of four independent experiments for each panel.

undergo reorganization either during 4-AP treatment or during the sustained enhancement of the slope of EPSPs. Also, the reorganization of protein complexes resulting in the appearance of a $40 \mathrm{kDa}$ SNAP25-caveolin band occurred in the absence of any apparent reorganization of any of the other syntaxin-, SNAP25-, or VAMPcontaining bands.

Figure $6 C$ shows that the $40 \mathrm{kDa}$ SNAP25-caveolin complex can be detected after overexposure in both control hippocampal slices and hippocampal slices after the washout of 4-AP. The $40 \mathrm{kDa}$ SNAP25-caveolin band was the lower band of a doublet that could be detected with anti-SNAP25 after overexposure. These results demonstrate that the $40 \mathrm{kDa}$ SNAP25-caveolin complex is present in hippocampal slices before 4-AP treatment at low levels. The presence of the $40 \mathrm{kDa}$ SNAP25-caveolin complex in control slices may reflect low abundance in many neurons or very high abundance in subsets of neurons in a hippocampal slice. Figure 7 shows that the induction of the $40 \mathrm{kDa}$ SNAP25-caveolin band by $10 \mathrm{~mm}$ 4-AP is blocked by preincubation of the hippocampal slice with 1 $\mu \mathrm{M}$ tetrodotoxin, $50 \mu \mathrm{M}$ D-2,5-aminophosphonovaleric acid, and $100 \mu \mathrm{M} \mathrm{CdCl}{ }_{2}$. These agents block voltage-dependent sodium channels, calcium channels, and NMDA receptors, respectively, and thus remove the electrogenic effects of 4-AP. This treatment, a control for possible $\mathrm{pH}$ effects of 4-AP, prevented the formation of the caveolin-SNAP25 complex, leaving it at control levels.

The specificity of the antisera used to identify the SNAP25caveolin complex is shown in Figure $8 \mathrm{~B}$. Anti-caveolin polyclonal and anti-caveolin1 polyclonal detect caveolin in both hippocampal and endothelial homogenates. Preincubation of either antisera with a peptide encoding the $\mathrm{N}$ terminal of caveolin1 (Santa Cruz Biotechnology) blocks the detection of caveolin in the hippocampus. That the detection of hippocampal caveolin was blocked by preincubation with the N-terminal peptide indicates that the caveolin immunoreactivity observed in rat hippocampus is specific and that the caveolin isoform expressed in rat hippocampus is caveolin1. In contrast, endothelial cells were observed to express more than one isoform of caveolin. Taken together these results demonstrate that a relatively rare SNAP25-caveolin interaction becomes an abundant protein complex during the induction of chemical-induced synaptic potentiation in rat hippocampal slices.

The observation that SNAP25 and caveolin form a complex in intact slices is consistent with reports that several proteins having posttranslational lipid modifications copurify with caveolin, including GTPases, tyrosine kinases, and glycosylphosphatidylinositol (GPI)-linked proteins (Smart et al., 1999). Figure $9 A$ shows that caveolin and recombinant immobilized SNAP25 form a direct interaction in vitro. Conversely, caveolin forms only a very weak interaction with recombinant immobilized VAMP. Many resident caveolae proteins are lipid-modified proteins, including G-proteins, tyrosine kinases, and GPI-linked proteins. In some cases lipidation is a requirement for inclusion of the protein into caveolae (Okamoto et al., 1998; Smart et al., 1999). Figure 9B demonstrates that SNAP25 coprecipitates with anti-caveolin polyclonal and anticaveolin1 polyclonal but not nonimmune serum or protein $\mathrm{A} / \mathrm{G}$ agarose. Taken together these results suggest that the interaction between caveolin and SNAP25 in rat hippocampus is specific and occurs in intact tissue. During the induction phase of potentiation, the formation of this complex is favored. Because caveolin forms a complex with recombinant SNAP25 that lacks any posttranslational modification, lipidation is not absolutely required for the SNAP25caveolin interaction. Note that the $40 \mathrm{kDa}$ complex migrates at a slightly lower position than the predicted molecular weights of SNAP25 (25 kDa) and caveolin (22 kDa) would predict, which may reflect altered palmitoylation of either protein.

Figure 10 demonstrates that caveolin and SNAP25 are enriched in isolated hippocampal nerve terminals (synaptosomes). Syntaxin and VAMP, other proteins involved in excitation-secretion coupling, are also shown to be abundant synaptosomal proteins. The coenrichment of caveolin and SNAP25 in hippocampal synaptosomes indicates that the caveolin1-SNAP25 interaction occurs at the synapse and is not a contribution by non-neuronal hippocampal cells. Figure 11 clearly shows that both SNAP25 and caveolin 1 are present in hippocampal neurons. Two caveolin antibodies, an anticaveolin1 polyclonal (Santa Cruz Biotechnology; Fig. 11A,B,D) and an anti-caveolin1 monoclonal (Transduction Laboratories; Fig. $11 C$ ), detect significant amounts of this protein in both neurons and glia. A third anti-caveolin polyclonal (Transduction Laboratories) confirmed our observations seen with the other two antibodies (data not shown). Furthermore, both caveolin1 and SNAP25 were colocalized in axonal varicosities (Fig. 11B). Caveolin1 was also observed to be abundant in axonal growth cones (Fig. 11C1) and dendritic spine-like structures (Fig. 11C2,C3). The caveolin staining was specific because staining was blocked by preincubation of 
A
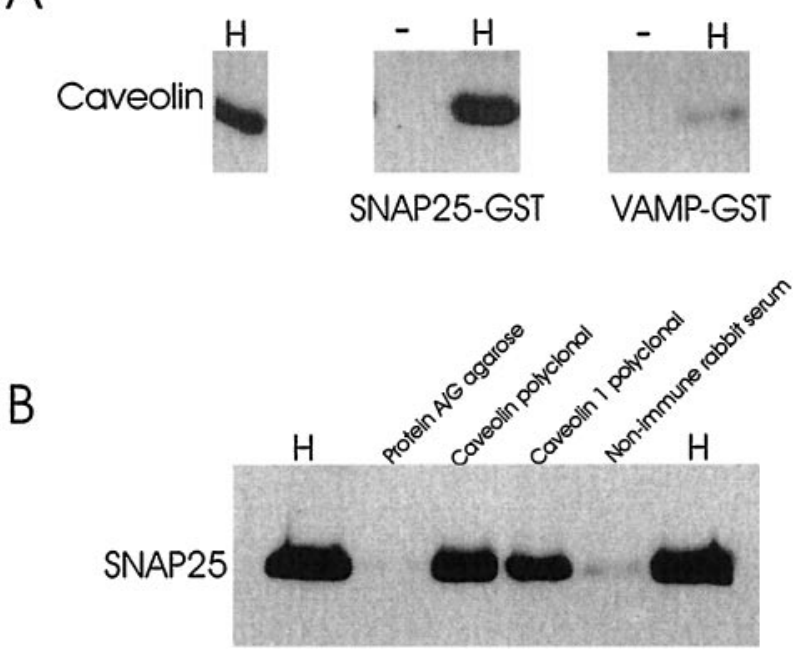

Figure 9. A, Binding of caveolin to SNAP25-GST and VAMP2-GST fusion proteins immobilized on agarose. SNAP25-GST and VAMP-GST fusion proteins were incubated in the presence or absence of $160 \mu \mathrm{g}$ of rat brain hippocampal homogenate for $30 \mathrm{~min}$ at $37^{\circ} \mathrm{C}$. The beads were washed, and bound proteins were eluted in sample buffer, fractionated by SDSPAGE, and subjected to Western blot analysis. The nitrocellulose membrane was probed with anti-caveolin polyclonal (Transduction Laboratories). The lanes are as follows: panel 1(left), lane $H, 8 \mu \mathrm{g}$ of rat brain hippocampal homogenate; panel 2, lane -, SNAP25-GST immobilized on glutathione agarose in the absence of hippocampal homogenate; lane $H$, SNAP25-GST agarose incubated in the presence of homogenate; panel 3, lane -, VAMP2-GST agarose in the absence of hippocampal homogenate; lane $H$, VAMP2-GST agarose incubated in the presence of homogenate. The interaction of caveolin with SNAP25 and VAMP2 was compared. $B$, Immunoprecipitation of caveolin-containing protein complexes from rat hippocampal homogenate followed by immunoblot analysis with antiSNAP25. Immunoprecipitation was achieved by incubating $180 \mu \mathrm{g}$ of hippocampal homogenate with affinity-purified anti-caveolin or anti-caveolin1 The lanes indicate incubations of rat brain hippocampal homogenate $(H ; 35$ $\mu \mathrm{g})$ or hippocampal homogenate $(160 \mu \mathrm{g})$ with protein $\mathrm{A} / \mathrm{G}$ agarose, caveolin polyclonal (Transduction Laboratories), caveolin1 polyclonal (Santa Cruz Biotechnology), or rabbit nonimmune serum. These results are representative of four independent experiments.

the anti-caveolin1 polyclonal with a peptide encoding the $\mathrm{N}$ terminal of caveolin1 (Santa Cruz Biotechnology; Fig. 11D3). The peptide did not block SNAP25 staining (Fig. 11D2). We did not detect SNAP25 in glia (Fig. 11D1). This alone suggests that the SNAP25caveolin complex is neuronal in origin.

No differences were observed in other VAMP, syntaxin, or SNAP25 protein complexes identified from control and hippocampal slices having persistent synaptic potentiation, suggesting that the core protein machinery underlying the synaptic vesicle life cycle is not reorganized in a detectable manner during an increase in synaptic strength. The significance of the $40 \mathrm{kDa}$ complex in the secretory pathway will be the goal of future studies. The $40 \mathrm{kDa}$ complex is not immunoreactive with VAMP, rab3a, or complexin I or II (data not shown). An additional calmodulin-containing complex was identified during the induction of potentiation with 4-AP. This calmodulin-containing complex did not comigrate with the 40 kDa SNAP25-caveolin complex but had a slightly higher molecular weight (Fig. 8A, panel 3). Like the $40 \mathrm{kDa}$ SNAP25-caveolin complex, the calmodulin complex may be involved in synaptic plasticity. These results do not preclude that presynaptic changes not assayed in these experiments mediate the 4-AP-induced sustained potentiation.

\section{DISCUSSION}

Current models of the biochemical pathway that underlies synaptic transmission suggest that specific presynaptic proteins do not act independently. Numerous studies have suggested that soluble as well as vesicle and plasma membrane-anchored proteins underlying secretion function by interacting with each other to form protein

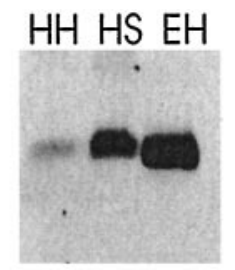

Anti-caveolin

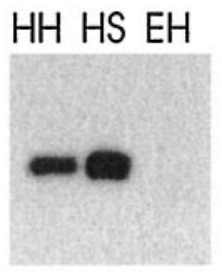

Anti-syntaxin

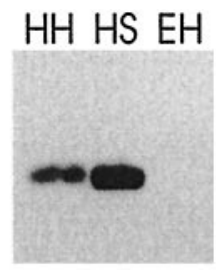

Anti-SNAP25

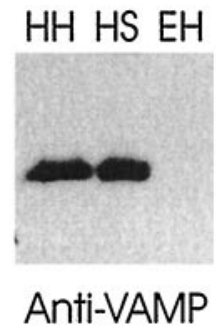

Figure 10. Immunoblot analysis of rat hippocampal homogenate $(\mathrm{HH} ; 40$ $\mu \mathrm{g})$, rat hippocampal synaptosomes $(H S ; 40 \mu \mathrm{g})$, and human vein endothelial cells $(E H ; 0.5 \mu \mathrm{g})$. Membranes were probed with anti-caveolin polyclonal (Transduction Laboratories), anti-SNAP25 monoclonal (Sternberger Monoclonals), anti-syntaxin monoclonal (Sigma), and anti-VAMP polyclonal (Stressgen Biotech) and visualized by ECL. Caveolin is shown to be an abundant synaptosomal protein. The results are representative of four independent experiments.

complexes (Bennett et al., 1992; Sollner et al., 1993a,b). Such complexes are thought to be dynamic, so that the precise assembly, rearrangement, and disassembly of a series of complexes underlie synaptic transmission (for review, see DeCamilli and Takei, 1996; Hay and Scheller, 1997; Fernandez-Chacon and Sudhof, 1999). Several studies have demonstrated that syntaxin, SNAP25, and other neuronal proteins proposed to have a direct function in synaptic vesicle exocytosis form stable interactions in solubilized rat brain membranes (Sollner et al., 1993a,b; Hayashi et al., 1994; Pevsner et al., 1994; Pellegrini et al., 1995). These protein complexes can also be assembled in vitro using recombinant proteins that lack their transmembrane domains (syntaxin and VAMP) or their posttranslationally added palmitoyl side chains (SNAP25) (Chapman et al., 1994; Pevsner et al., 1994; Hanson et al., 1995; McMahon and Sudhof, 1995). The domains essential for interactions among these proteins have been mapped by truncation, deletion, and site-directed mutagenesis analysis (Calakos et al., 1994; Chapman et al., 1994; Hayashi et al., 1994; Kee et al., 1995; Hao et al., 1997; Poirier et al., 1998). Importantly, the structure of the syntaxin, VAMP, and SNAP25 complex has been resolved (Fernandez et al., 1998; Sutton et al., 1998; Poirier et al., 1999). Despite the detailed structural and biochemical information, the nature of syntaxin, VAMP, and SNAP25 interactions in intact neurons remains unknown.

This study establishes the presence of multiple SNAP25, syntaxin, and VAMP protein complexes in intact functioning hippocampal slices before detergent solubilization using a strategy of rapid protein cross-linking. Cross-linked SNAP25 complexes were identified at 55, 60, and $100 \mathrm{kDa}$. Cross-linked syntaxin complexes were identified at 60, 100, and $120 \mathrm{kDa}$. Cross-linked VAMP complexes were identified at 35, 55, 100, and $120 \mathrm{kDa}$. One of these cross-linked complexes, the $100 \mathrm{kDa}$ VAMP, syntaxin, and SNAP25-containing complex, appeared to be identical to a complex described previously in in vitro studies. A $55 \mathrm{kDa}$ VAMP-synaptophysin complex was also confirmed in the hippocampal slices. The 55 and $60 \mathrm{kDa}$ SNAP25 complexes, the 60 and $120 \mathrm{kDa}$ syntaxin complexes, and the 35 and $55 \mathrm{kDa}$ VAMP complexes likely represent protein complexes that are short-lived. These novel complexes may be intermediates in the exocytotic-endocytotic cycle that are fleeting and therefore not maintained during deter- 

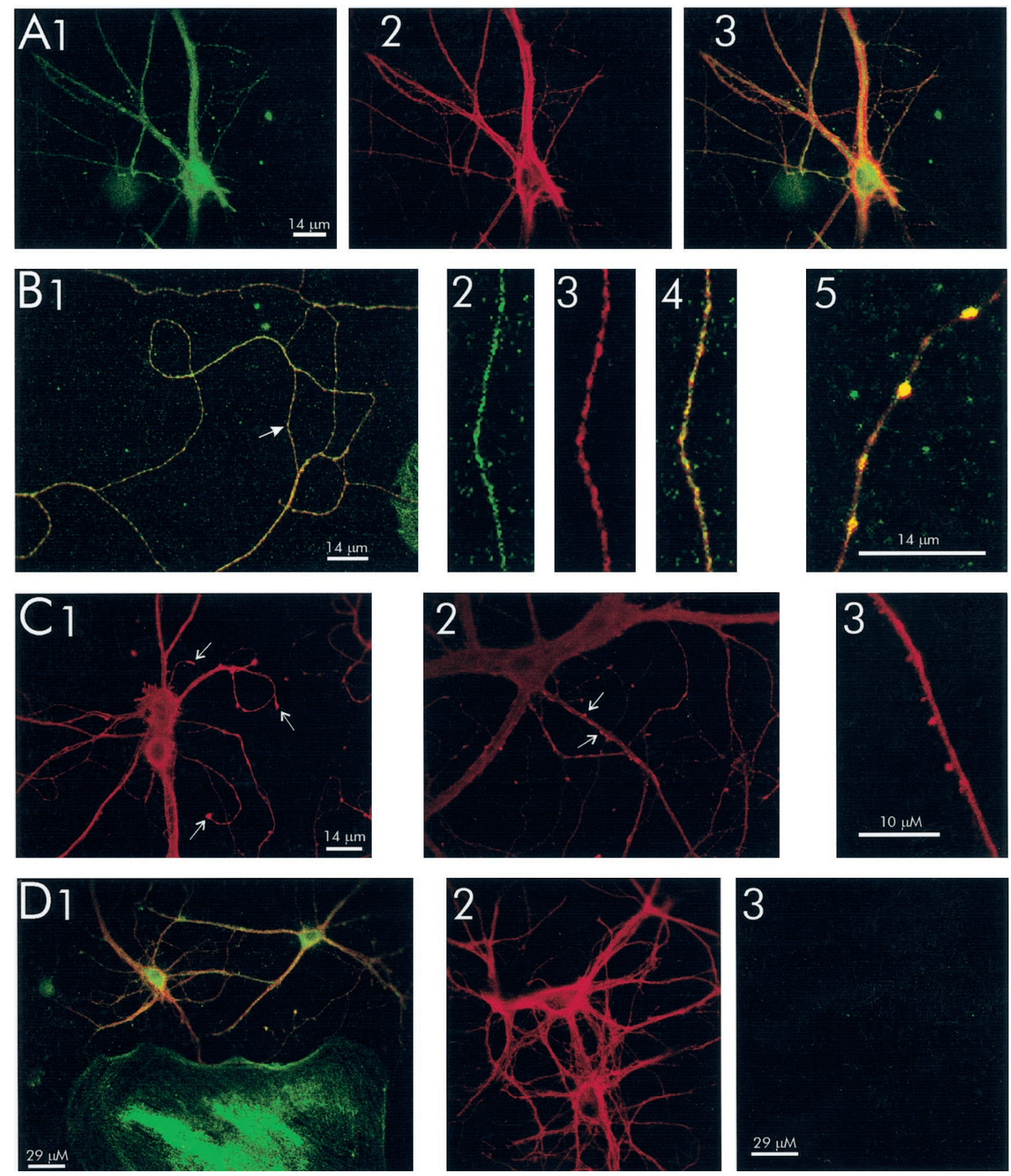

Figure 11. A, Colocalization of caveolin1 and SNAP25 in hippocampal neurons. Neurons were stained with anti-caveolin1 polyclonal (A1; Santa Cruz Biotechnology) and anti-SNAP25 monoclonal (A2; Sternberger Monoclonals). Colocalization of caveolin1 and SNAP25 (A3) is shown. B, Colocalization of caveolin1 and SNAP25 in axonal varicosities. Neurons were stained with anti-caveolin1 polyclonal (B2) and anti-SNAP25 monoclonal (B3) antibodies. The arrow in B1 indicates the region of the axon shown in B2-B4. Colocalization of caveolin1 and SNAP25 is shown in B1, B4, and B5. C, Localization of caveolin1 in hippocampal neurons. Neurons were stained with anti-caveolin1 monoclonal (C1-C3). Arrows indicate growth cones (C1) and dendritic spine-like caveolin hot spots $(C 2, C 3)$. Caveolin1 is present in both neurons and glia $(D 1, B 1)$. SNAP25 and caveolin1 are both present in hippocampal neurons, but SNAP25 is absent in glial cells including astrocytes (green). D. Hippocampal cultures were stained with caveolin1 polyclonal and SNAP25 monoclonal. Specificity of the caveolin1 polyclonal antibody is shown $(D 2, D 3)$. Neurons were stained with anti-caveolin1 preincubated for 1 hr with blocking (antigen) peptide (Santa Cruz Biotechnology) and SNAP25 monoclonal (D2, D3). SNAP25 staining (D2) and caveolin1 staining (D3) are shown.

gent solubilization. The presence of multiple SNAP25- and syntaxin-containing complexes within a single hippocampal slice may reflect different states of SNAP25 and syntaxin in different neurons and/or multiple states within a given synapse (e.g., SDS core vs $7 \mathrm{~S}$ vs $20 \mathrm{~S}$ SNARE complexes). In addition, it has been found that secretory vesicles as well as the plasma membrane contain SNAP25 and syntaxin (Tagaya et al., 1995; WalchSolimena et al., 1995). Multiple SNAP25- and syntaxin-containing 
complexes within a single hippocampal slice may reflect a complement of synaptic vesicle complexes, plasma membrane complexes, and synaptic vesicle-plasma membrane cocomplexes. The monomer forms of SNAP25 and syntaxin were also detected in fractions obtained from cross-linked hippocampal slices (2-45 min of paraformaldehyde). That the entire pool of hippocampal syntaxin and SNAP25 did not cross-link suggests the existence of free syntaxin and SNAP25 in the hippocampal slice preparation. The presence of free syntaxin and SNAP25 is in agreement with studies using clostridial neurotoxins, the most potent inhibitors of neurotransmitter release known (for review, see Montecucco and Schiavo, 1993). Tetanus and botulinum toxins specifically proteolyze VAMP, syntaxin, and SNAP25 primarily by attacking the free, and not the complexed, forms of these proteins. Our results are consistent with those of Raciborska et al. (1998) who identified distinct populations of SNARE proteins on the basis of their susceptibility to clostridial neurotoxins.

An increasing variety of SNAP25-containing complexes has been reported in solubilized brain preparations including a 7 S SNARE complex composed of syntaxin, SNAP25, VAMP, and synaptotagmin (Sollner et al., 1993a,b); an SDS-resistant SNARE core complex composed of syntaxin, SNAP25, and VAMP (Hayashi et al., 1994); a 20 S SNARE complex composed of NSF, $\alpha$-SNAP, syntaxin, SNAP25, VAMP, and synaptotagmin; a $\mathrm{Ca}^{2+}$ channel, syntaxin, VAMP, and SNAP25 complex (Martin-Moutot et al., 1996); a complex consisting of VAMP, SNAP25, syntaxin, and complexin I and II (McMahon et al., 1995); a complex composed of SNAP25 and HRS2 (Bean et al., 1997); and a $10 \mathrm{~S}$ complex consisting of tomosyn, syntaxin, and SNAP25 (Fujita et al., 1998). The techniques used to identify these protein complexes favor the identification of stable, high-affinity protein-protein interactions. It is likely, however, that a series of fleeting protein-protein interactions mediates synaptic transmission and that short-lived protein complexes cannot be determined by these techniques.

A novel $40 \mathrm{kDa}$ SNAP25-caveolin protein complex was identified during the induction of potentiation with 4-AP but did not correlate with sustained potentiation (Fig. 6). The caveolinSNAP25 interaction was confirmed biochemically by the association of caveolin with recombinant immobilized SNAP 25 and by the coimmunoprecipitation of SNAP25 using caveolin-specific antisera (Fig. 9). Caveolins are a family of proteins that form the principal structure of flasked-shaped invaginations or caves of the plasma membrane called caveolae, thereby organizing and concentrating specific molecules in discrete regions of the plasma membrane (for review, see Parton, 1996; Simons and Ikonen, 1997; Okamoto et al., 1998; Smart et al., 1999). Although initially identified as plasma membrane invaginations of $50-100 \mathrm{~nm}$, it is now known that caveolae can also be (1) flat within the plane of the plasma membrane, (2) large grape-like structures, (3) tubules, or (4) detached vesicles. Caveolae have a unique lipid composition. They are discrete lipid microdomains within the plasma membrane caused by the preferential packing of sphingolipids and cholesterol. In contrast, noncaveolar regions of the plasma membrane are typically composed of phospholipids. Current reports indicate that caveolae can be customized for different functions. A role for caveolae in (1) potocytosis, (2) transcytosis, (3) polarized trafficking of proteins, (4) cholesterol transport, and (5) regulation of signal transduction events has been proposed (for review, see Smart et al., 1999). Four different caveolin isoforms encoded by three genes have been described: caveolin $1 \alpha,-1 \beta,-2$, and -3 . The caveolin isoform expressed in the rat hippocampus is caveolin 1 on the basis of immunoprecipitation (Fig. 9), immunoblot analysis (Fig. 10), and immunocytochemistry (Fig. 11). Despite its central role in plasma membrane function, the molecular mechanisms mediating and regulating caveolar trafficking at the cell surface are primarily unknown (for review, see Parton, 1996; Simons and Ikonen, 1997; Okamoto et al., 1998).

Until recently caveolin was thought to be absent from the nervous system (Cameron et al., 1997; Galbiati et al., 1998; Ikezu et al., 1998; Mikol et al., 1999). Conflicting reports likely arose from the detergent resistance of caveolae and the absence of caveolin in many commonly used cell lines. In fact, the absence of caveolin in several previous reports of SNAP25-interacting proteins (Pevsner et al., 1994) is likely caused by caveolin's detergent insolubility under most conditions. The unique lipid composition of caveolae accounts for the insolubility in many detergents. This study establishes that caveolin1 and SNAP25 are both present in hippocampal neurons. Caveolin1 hot spots were observed in axonal growth cones, axonal varicosities, and dendritic spine-like structures. Colocalization of SNAP25 and caveolin was obvious in axonal varicosities. Perhaps the $40 \mathrm{kDa}$ SNAP25-caveolin complex represents a transient change during the induction of synaptic potentiation that is important in the later developments of longterm plasticity. The lack of SNAP25 immunoreactivity in glia indicates that the SNAP25-caveolin complex isolated from whole tissue is neuronal in origin. This reorganization of protein complexes resulting in the appearance of a $40 \mathrm{kDa}$ SNAP25-caveolin band occurred in the absence of reorganization of any of the other syntaxin-, SNAP25-, or VAMP-containing bands.

A detailed understanding of neurotransmission and its physiological regulation (e.g., LTP and long-term depression) requires elucidation of the molecular mechanisms underlying the synaptic vesicle life cycle. The identification of changes in these and other protein complexes that occur during alterations in synaptic transmission is important to our understanding of neurotransmission. The strategy of rapid protein cross-linking in intact tissue together with currently used perturbation strategies [e.g., genetics, microinjection, and permeabilized cells (for review, see Augustine et al., 1996)] will establish the protein dynamics underlying neurosecretion and its modification.

\section{REFERENCES}

Ahmari SE, Buchanan J, Smith SJ (2000) Assembly of presynaptic active zones from cytoplasmic transport packets. Nat Neurosci 3:445-451.

Aniksztejn L, Ben-Ari Y (1991) Novel form of long-term potentiation produced by a $\mathrm{K}+$ channel blocker in the hippocampus. Nature 349:67-69.

Augustine GJ, Burns ME, DeBello WM, Pettit DL, Schweizer FE (1996) Exocytosis: proteins and perturbations. Annu Rev Pharmacol Toxicol 36:659-701.

Banker G, Goslin K (1998) Culturing nerve cells. Cambridge, MA: MIT. Bean AJ, Seifert R, Chen YA, Sacks R, Scheller RH (1997) Hrs-2 is an ATPase implicated in calcium-regulated secretion. Nature 385:826-829.

Bennett MK, Calakos N, Kreiner T, Scheller RH (1992) Synaptic vesicle membrane proteins interact to form a multimeric complex. J Cell Biol 116:761-775.

Betz A, Ashery U, Rickmann M, Augustin I, Neher E, Sudhof TC, Rettig J, Brose N (1998) Munc13-1 is a presynaptic phorbol ester receptor that enhances neurotransmitter release. Neuron 21:123-136.

Braun JE, Scheller RH (1995) Cysteine string protein, a DnaJ family member, is present on diverse secretory vesicles. Neuropharmacology 34:1361-1369.

Calakos N, Scheller RH (1994) Vesicle-associated membrane protein and synaptophysin are associated on the synaptic vesicle. J Biol Chem 269:24534-24537.

Calakos N, Bennett MK, Peterson KE, Scheller RH (1994) Proteinprotein interactions contributing to the specificity of intracellular vesicular trafficking. Science 263:1146-1148.

Cameron PL, Ruffin JW, Bollag R, Rasmussen H, Cameron RS (1997) Identification of caveolin and caveolin-related proteins in the brain. J Neurosci 17:9520-9535.

Chapman ER, An S, Barton N, Jahn R (1994) SNAP-25, a t-SNARE which binds to both syntaxin and synaptobrevin via domains that may form coiled coils. J Biol Chem 269:27427-27432.

DeCamilli P, Takei K (1996) Molecular mechanisms in synaptic vesicle endocytosis and recycling. Neuron 16:481-486.

Fawcett JP, Aloyz R, Mclean JH, Pareek S, Miller FD, McPherson PS, Murphy RA (1997) Detection of brain-derived neurotrophic factor in a vesicular fraction of brain synaptosomes. J Biol Chem 272:8837-8840.

Fernandez I, Ubach J, Dulubova I, Hang X, Sudhof TC, Izo J (1998) Three-dimensional structure of an evolutionarily conserved N-terminal domain of syntaxin 1A. Cell 94:841-849.

Fernandez-Chacon R, Sudhof TC (1999) Genetics of synaptic vesicle function: toward the complete functional anatomy of an organelle. Annu Rev Physiol 61:753-776.

Fujita Y, Shirataki H, Sakisasa T, Asakura T, Ohya T, Kotani H, Yokoyama S, Nishioka H, Matsuura Y, Mizoguchi A, Scheller RH, Takai Y (1998) Tomosyn: a syntaxin-1-binding protein that forms a novel complex in the neurotransmitter release process. Neuron 20:905-915. 
Galbiati F, Volonte D, Gil O, Zanazzi G, Salzer JL, Sargiacomo M, Scherer PE, Engelman JA, Schlegel A, Parenti M, Okamoto T, Lisanti MP (1998) Expression of caveolin-1 and -2 in differentiating PC12 cells and dorsal root ganglion neurons: caveolin-2 is up-regulated in response to cell injury. Proc Natl Acad Sci USA 95:10257-10262.

Gillis KD, Mobner R, Neher N (1996) Protein kinase C enhances exocytosis from chromaffin cells by increasing the size of the readily releasable pool of secretory granules. Neuron 16:1209-1220.

Guan KL, Dixon JE (1991) Eukaryotic proteins expressed in Escherichia coli: an improved thrombin cleavage and purification procedure of fusion proteins with glutathione $S$-transferase. Anal Biochem 192:262-267.

Hanson PI, Otto H, Barton N, Jahn R (1995) The N-ethylmaleimidesensitive fusion protein and a-SNAP induce a conformational change in syntaxin. J Biol Chem 270:16955-16961.

Hao JC, Salem N, Peng XR, Kelly RB, Bennett MK (1997) Effect of mutations in vesicle-associated membrane protein (VAMP) on the assembly of multimeric protein complexes. J Neurosci 17:1596-1603.

Hay JC, Scheller RH (1997) SNAREs and NSF in targeted membrane fusion. Curr Opin Cell Biol 9:505-512.

Hayashi T, McMahon H, Yamasaki S, Binz T, Hata Y, Sudhof TC, Niemann H (1994) Synaptic vesicle membrane fusion complex: action of clostridial neurotoxins on assembly. EMBO J 13:5051-5061.

Ikezu T, Ueda H, Trapp BD, Nishiyama K, Sha JF, Volonte D, Galbiati F, Byrd AL, Bassell G, Serizawa H, Lane WS, Lisanti MP, Okamoto T (1998) Affinity-purification and characterization of caveolins from the brain: differential expression of caveolin-1, -2 , and -3 in brain endothelial and astroglial cell types. Brain Res 804:177-192.

Kee Y, Lin RC, Hsu SC, Scheller RH (1995) Distinct domains of syntaxin are required for synaptic vesicle fusion complex formation and dissociation. Neuron 14:991-998.

Martin-Moutot N, Charvin N, Leveque C, Sato K, Nishiki T, Kozake S, Takahashi M, Seagar M (1996) Interaction of SNARE complexes with $\mathrm{P} / \mathrm{Q}$-type calcium channels in rat cerebellar synaptosomes. J Biol Chem 271:6567-6570.

McMahon HT, Sudhof TC (1995) Synaptic core complex of synaptobrevin, syntaxin, and SNAP25 forms high affinity a-SNAP binding site. J Biol Chem 270:2213-2217.

McMahon HT, Missler M, Li C, Sudhof TC (1995) Complexins: cytosolic proteins that regulate SNAP receptor function. Cell 83:111-119.

Meffert MK, Premack BA, Schulman H (1994) Nitric oxide stimulates $\mathrm{Ca} 2+$-independent synaptic vesicle release. Neuron 12:1235-1244.

Mikol DD, Hong HL, Cheng H, Feldman EL (1999) Caveolin-1 expression in Schwann cells. Glia 27:39-52.

Montecucco C, Schiavo G (1993) Tetanus and botulism neurotoxins: a new group of zinc proteases. Trends Biochem Sci 18:324-327.

Nagy A, Delgado-Escuta AV (1984) Rapid preparation of synaptosomes from mammalian brain using nontoxic isoosmotic gradient material (Percoll). J Neurochem 43:1114-1123.

Okamoto T, Schlegel A, Scherer PE, Lisanti MP (1998) Caveolins, a family of scaffolding proteins for organizing "preassembled signaling complexes" at the plasma membrane. J Biol Chem 273:5419-5422.
Parton RG (1996) Caveolae and caveolins. Curr Opin Cell Biol 8:542-548

Pellegrini LL, O'Connor V, Lottspeich F, Betz H (1995) Clostridial neurotoxins compromise the stability of a low energy SNARE complex mediating NSF activation of synaptic vesicle fusion. EMBO J 14:4705-4713.

Pevsner J, Hsu SC, Braun JE, Calakos N, Ting AE, Bennett MK, Scheller RH (1994) Specificity and regulation of a synaptic vesicle docking complex. Neuron 13:353-361.

Poirier MA, Hao JC, Malkus PN, Chan C, Moore MF, King DS, Bennett MK (1998) Protease resistance of syntaxin.SNAP-25.VAMP complexes. Implications for assembly and structure. J Biol Chem 273:11370-11377.

Poirier MA, Xiao W, Macosko JC, Chan C, Shin Y, Bennett MK (1999) The synaptic SNARE complex is a parallel four-stranded helical bundle. Nat Struct Biol 5:765-769.

Raciborska DA, Trimble WS, Charlton MP (1998) Presynaptic protein interactions in vivo: evidence from botulinum $\mathrm{A}, \mathrm{C} 1, \mathrm{D}$ and $\mathrm{E}$ action at frog neuromuscular junction. Eur J Neurosci 10:2617-2628.

Rosahi TW, Spillane D, Missler M, Herz J, Selig DK, Wolff JR, Hammer DE, Malenka RC, Sudhof TC (1995) Essential functions of synapsins I and II in synaptic vesicle regulation. Nature 375:488-493.

Schweizer FE, Dresbach T, DeBello WM, O'Connor V, Betz H (1998) Regulation of neurotransmitter release kinetics by NSF. Science 279:1203-1206.

Simons K, Ikonen E (1997) Functional rafts in cell membranes. Nature 387:569-572.

Smart EJ, Graf GA, McNiven MA, Sessa WC, Engelman JA, Scherer PE, Okamoto T, Lisanti MP (1999) Caveolins, liquid-ordered domains, and signal transduction. Mol Cell Biol 19:7289-7304.

Sollner T, Whiteheart SW, Brunner M, Erdjument-Bromage H, Geromanos S, Tempst P, Rothman JE (1993a) SNAP receptors implicated in vesicle targeting and fusion. Nature 362:318-324.

Sollner T, Bennett MK, Whiteheart SW, Scheller RH, Rothman JE (1993b) A protein assembly-disassembly pathway in vitro that may correspond to sequential steps of synaptic vesicle docking, activation, and fusion. Cell 75:409-418.

Sutton RB, Fasshauer D, Jahn R, Brunger AT (1998) Crystal structure of a SNARE complex involved in synaptic exocytosis at 2.4 A resolution. Nature 395:347-353.

Tagaya M, Toyonaga S, Takahashi M, Yamamoto A, Fujiwara T, Akagawa K, Moriyama Y, Mizushima S (1995) Syntaxin 1 (HPC-1) is associated with chromaffin granules. J Biol Chem 270:15930-15933.

Takei K, Mundigl O, Daniell L, De Camilli P (1996) The synaptic vesicle cycle: a single vesicle budding step involving clathrin and dynamin. J Cell Biol 133:1237-1250.

Walch-Solimena C, Blasi J, Edelmann L, Chapman ER, Von Mollard GF, Jahn R (1995) The t-SNAREs syntaxin and SNAP25 are present on organelles that participate in synaptic vesicle recycling. J Cell Biol 128: $637-645$. 